\title{
LA LIBERTAD, LA JUSTICIA, EL LUJO: EL MUNDO CLÁSICO. LA EPOPEYA DE GRECIA Y ROMA, DE ROBIN LANE FOX*
}

\author{
Miguel Vélez San Martín
}

"Es todo un reto que le pidan a uno escribir una historia de casi novecientos años, especialmente cuando los testimonios son tan fragmentarios y diversos, pero es un reto con el que he disfrutado mucho. No he dado por supuesta en el lector ninguna familiaridad con el tema, pero espero que tanto los que la tienen como los que no la tienen se sientan atraídos y entretenidos por lo que me ha dado tiempo a estudiar en estas páginas." Con esta invitación, el historiador Robin Lane Fox abre el libro El Mundo Clásico. La epopeya de Grecia y Roma (2008), un relato que acomete para iluminar, desde el siglo XXI, el universo de los dos pueblos que dieron origen a la cultura occidental.

Los ingleses, y en general los anglosajones, poseen un sentido especial para hacer historia, biografías, memorias, etc., es decir, libros de no ficción que sin embargo se benefician de las mejores cualidades de la escritura literaria: son libros escritos para que se lean, para entretener, para que quienes se entreguen a su lectura no se sientan necesariamente ante un esfuerzo permanente, sino ante unas páginas a las que se desea volver. Relatar la evolución social, cultural y política de Grecia y Roma durante el transcurso de casi mil años, esto es, desde los poemas de Homero a la época del emperador Adriano, sin que la pasión y el placer de la lectura amainen, es sin duda un reto de dimensiones épicas, cuya tarea el autor no solo la afronta con audacia, sino que la resuelve con maestría.

Sin caer en la habitual idealización de ese mundo -pues "los que idealizan el pasado suelen no entenderlo"-, Lane Fox sobrevuela los esplendores del universo antiguo, su creatividad, su patetismo y sus aspectos más revolucionarios, todo ello con un profundo sentido de lo humano. El punto de partida es, además, original: ha vuelto al mundo clásico explorando cómo se entendieron entonces tres cuestiones: la libertad, la justicia y el lujo.

El libro recorre con detalle el devenir ideológico asociado a estos tres conceptos, así como la cultura y sensibilidad que generaron en ese lejano mundo y también, por cierto, en el nuestro. Lane Fox describe con singular agudeza las figuras que marcan con su personal genio los momentos estelares de Grecia y Roma, tanto si trata de la aristocracia griega arcaica, o de los avatares de la polis y la democracia, o de Platón y Aristóteles, o de Pompeya y la vida cotidiana, o de Augusto o Plinio o Adriano.

Su análisis de Homero tiene visos de devoción: "Inventó la nostalgia", dice, "fue quien supo llenar con historias y palabras ese agujero que hiere en las entrañas cuando

* Fox, Robin Lane, El Mundo Clásico. La epopeya de Grecia y Roma, Traductores: Teófilo de Loyoza y Juan Rabasseda-Gascón, Barcelona: Crítica, 2007. 
uno está lejos de casa. También supo contar, de manera cruda y realista, lo que significan la gloria y la fama en esta vida, atrapó el dolor que nos abate ante la pérdida de los más próximos y mostró cómo los héroes se equivocan, y lo descubren en los momentos trágicos cuando ya es demasiado tarde." De modo que el relato de Lane Fox se ovilla en un ida y vuelta desde Heródoto a Adriano y, de pronto, se detiene en un análisis de la atrocidad olímpica de Bush y Blair, con respecto a la guerra de Irak, todo ello en una defensa contemporánea de los valores humanistas de Grecia y Roma, aunque insiste en que hay que contextualizarlos en una época que toleraba la esclavitud. Aquel viejo mundo, el de los héroes trágicos y la filosofía, la democracia y la ley, el circo y la esclavitud, terminó con la llegada del cristianismo. "El dominio del pecado se introdujo en el mundo y se habló de la salvación de los cuerpos, ese tremendo absurdo". Lane Fox recalca que los cristianos no estaban en contra de la esclavitud, sino que hablaban de libertad espiritual: el cambio social era irrelevante. La verdadera alternativa era el cielo y, para ellos, el lujo y la riqueza eran un obstáculo para la salvación.

Se le ha preguntado en más de una entrevista a Robin Lane Fox por el legado griego, a lo que este historiador, nacido en 1946 y referente indiscutible del mundo clásico en la Universidad de Oxford, señala: "La democracia, el teatro, las carreras de caballos, la arquitectura, las matemáticas, la belleza, la homosexualidad, el amor...". Sobre el gran invento de occidente, el amor, afirma: "Ya lo dijo Stendhal, que sin el juego de referencias, sin las batallas de la seducción, sin las palabras que otros dieron a sus emociones, el amor solo sería un mero trámite carnal sin ningún interés". Según Lane Fox, eso fue precisamente lo que inventaron los griegos: darle densidad y vida a lo que forma parte de nuestra naturaleza y convertirlo en algo que merece la pena.

Con una traducción superlativa de Teófilo de Lozoya y Juan Rabasseda-Gascón, y una excelente anotación de las fuentes existentes sobre cada uno de los temas tratados, esta historia actúa como el centro estabilizador de los muchos estudios y libros que durante estas últimas décadas de investigación histórica han hecho avanzar en el conocimiento de una cultura tan distante en el tiempo.

El Mundo Clásico. La epopeya de Grecia y Roma está editado por Crítica, tiene 825 páginas, mapas, 62 ilustraciones, y está compuesto de seis grandes capítulos, que conforman, juntos, un libro excepcional: "El mundo griego arcaico", "El mundo griego clásico", "Los mundos helenísticos", "La república romana", "De la república romana", "De la república al Imperio" y "Un mundo imperial". 